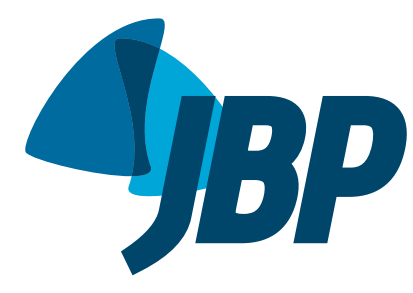

1. Centro de Reabilitação Pulmonar, Escola Paulista de Medicina, Universidade Federal de São Paulo, São Paulo (SP) Brasil.

2. Departamento de Medicina, Universidade Federal de São João Del Rei, São João Del Rei (MG) Brasil.

3. Divisão de Pneumologia, Pontifícia Universidade Católica do Rio Grande do Sul, Porto Alegre (RS) Brasil.

4. Divisão de Pneumologia, Hospital Otávio de Freitas, Recife (PE) Brasil.

5. Servicio de Neumología, Hospital Universitari Vall d'Hebron, Centro de Investigación Biomédica en Red de Enfermedades Respiratorias - CIBERES - Barcelona, España.

6. Departamento de Pneumologia, Hospital Geral de Goiânia Alberto Rassi, Goiânia (GO) Brasil.

7. Departamento de Biologia Molecular Associação Fundo de Incentivo à Pesquisa - AFIP - São Paulo (SP) Brasil.

8. Divisão de Pneumologia, Hospital do Servidor Público Estadual de São Paulo - HSPE-SP - São Paulo (SP) Brasil.

9. Departamento de Psicobiologia Universidade Federal de São Paulo, São Paulo (SP) Brasil.

10. Departamento de Pneumologia, Hospital de Messejana, Fortaleza (CE) Brasil.

Submitted: 5 September 2015 Accepted: 9 May 2016

Study carried out at the Centro de Reabilitação Pulmonar, Escola Paulista de Medicina, Universidade Federal de São Paulo, São Paulo (SP): in the Divisão de Pneumologia, Pontifícia Universidade Católica do Rio Grande do Sul, Porto Alegre (RS); in the Divisão de Pneumologia, Hospital Otávio de Freitas, Recife (PE): in the Departamento de Pneumologia, Hospital Geral de Goiânia Alberto Rassi, Goiânia (GO); in the Divisão de Pneumologia, Hospital do Servidor Público Estadual de São Paulo, São Paulo (SP): and in the Departamento de Pneumologia Hospital de Messejana, Fortaleza (CE) Brasil.

\section{Prevalence of alpha-1 antitrypsin deficiency and allele frequency in patients with COPD in Brazil}

\author{
Rodrigo Russo, ${ }^{1,2}$, Laura Russo Zillmer ${ }^{1}$, Oliver Augusto Nascimento', \\ Beatriz Manzano', Ivan Teruaki Ivanaga', Leandro Fritscher ${ }^{3}$, \\ Fernando Lundgren ${ }^{4}$, Marc Miravitlles 5 , Heicilainy Del Carlos Gondim6, \\ Gildo Santos Junior', Marcela Amorim Alves ${ }^{4}$, Maria Vera Oliveira ${ }^{8}$, \\ Altay Alves Lino de Souza ${ }^{9}$, Maria Penha Uchoa Sales ${ }^{10}$, José Roberto Jardim ${ }^{1}$
}

\begin{abstract}
Objective: To determine the prevalence of alpha 1-antitrypsin (AAT) deficiency (AATD), as well as allele frequency, in COPD patients in Brazil. Methods: This was a cross-sectional study involving 926 COPD patients 40 years of age or older, from five Brazilian states. All patients underwent determination of AAT levels in dried blood spot (DBS) samples by nephelometry. Those with DBS AAT levels $\leq 2.64 \mathrm{mg} / \mathrm{dL}$ underwent determination of serum AAT levels. Those with serum AAT levels of $<113 \mathrm{mg} / \mathrm{dL}$ underwent genotyping. In case of conflicting results, SERPINA1 gene sequencing was performed. Results: Of the 926 COPD patients studied, 85 had DBS AAT levels $\leq 2.64 \mathrm{mg} / \mathrm{dL}$, and $24(2.6 \%$ of the study sample) had serum AAT levels of $<113 \mathrm{mg} / \mathrm{dL}$. Genotype distribution in this subset of 24 patients was as follows: $\mathrm{PI}{ }^{*} \mathrm{MS}$, in $3(12.5 \%) ; \mathrm{PI}^{*} \mathrm{MZ}$, in $13(54.2 \%) ; \mathrm{PI}^{*} \mathrm{SZ}$, in $1(4.2 \%)$; $\mathrm{PI}^{*} \mathrm{SS}$, in $1(4.2 \%)$; and $\mathrm{PI}^{*} \mathrm{ZZ}$, in $6(25.0 \%)$. In the sample as a whole, the overall prevalence of AATD was $2.8 \%$ and the prevalence of the $P I^{*} Z Z$ genotype (severe AATD) was $0.8 \%$ Conclusions: The prevalence of AATD in COPD patients in Brazil is similar to that found in most countries and reinforces the recommendation that AAT levels be measured in all COPD patients.
\end{abstract}

Keywords: alpha 1-antitrypsin deficiency/epidemiology; pulmonary disease, chronic obstructive/epidemiology; Alleles; alpha 1-antitrypsin

\section{INTRODUCTION}

Alpha-1 antitrypsin (AAT) deficiency (AATD) is an autosomal codominant disorder primarily affecting the lungs and the liver. ${ }^{(1,2)}$ The incidence of AATD is 1 per 2,0005,000 live births; analysis of a database of 4.4 billion people from 58 countries estimated that 116 million individuals have the MS or MZ phenotype and that 3.4 million have the SS, SZ, or ZZ phenotype. ${ }^{(3,4)}$

AAT is a glycoprotein consisting of a chain of 394 amino acids and three carbohydrate side chains, being considered the prototype of a superfamily of proteins known as serpins (serine protease inhibitors). Also known as protease inhibitor (PI), AAT is encoded by the SERPINA1 gene, located on the long arm of chromosome 14 (14q32.1), and inhibits neutrophil elastase, trypsin, and protease-3.(3,5,6)

Although smoking is a major cause of airflow obstruction, it is estimated that only $15-30 \%$ of smokers develop COPD. ${ }^{(7-9)}$ Despite the clear association between smoking and COPD, the effects of smoking vary across individuals. ${ }^{(10)}$ Studies have shown that AATD can increase the impact of smoking on the lungs, resulting in an increased rate of decline in lung function and early emphysema in smokers. Mutant $\mathrm{S}$ and $\mathrm{Z}$ alleles are the most commonly involved in severe AATD. ${ }^{(11,12}$

The fact that the Brazilian population is racially diverse and includes immigrants from European countries where the frequency of alleles involved in early lung changes is high suggests that AATD is underdiagnosed in the country. Despite the estimated 5-7 million COPD patients in Brazil, ${ }^{(13)}$ the prevalence of AATD in this population remains unknown, as does allele frequency. Therefore, the objective of the present study was to assess the prevalence of AATD, as well as allele frequency, in COPD patients from five Brazilian states.

Correspondence to:

Rodrigo Russo. Departamento de Medicina, Universidade Federal de São João Del Rei, Praça Dom Helvécio, 74, Campus Dom Bosco (DCNAT), Sala 17, Fábrica, CEP 36301-160, São João Del Rei, MG, Brasil. 


\section{METHODS}

\section{Study design}

The present study was approved by the Research Ethics Committee of the Federal University of São Paulo Hospital São Paulo (Protocol no. 0633/10), located in the city of São Paulo, Brazil, as well as by the research ethics committees of all participating centers. Between July of 2011 and August of 2012, 1,073 COPD patients followed at any of the six participating centers (two in northeastern Brazil, two in southeastern Brazil, one in southern Brazil, and one in central-western Brazil) were evaluated.

\section{Patients}

The inclusion criteria were as follows: being 40 years of age or older; having been diagnosed with COPD (on the basis of clinical history and spirometry results, including a post-bronchodilator percent predicted $\mathrm{FEV}_{1} / \mathrm{FVC}$ ratio- $\mathrm{FEV}_{1} / \mathrm{FVC} \%$-below the lower limit of normal); and having been stable for at least four weeks. ${ }^{(14)}$ The exclusion criteria were as follows: having been diagnosed with any other lung disease or systemic disease that can increase serum AAT levels (including infections and inflammatory processes); having previously been diagnosed with AATD; being a relative of an index case of AATD; and having asthma (Figure 1).

The goal was to include 200 COPD patients from each participating center. At the end of the study period, no more patients were added to the study, regardless of whether or not the desired number of patients had been attained for each center.

\section{Spirometry}

The reference values for calculating percent predicted FVC, percent predicted $\mathrm{FEV}_{1}$, and $\mathrm{FEV}_{1} / \mathrm{FVC} \%$ were based on the National Health and Nutrition Examination Survey equations. ${ }^{(15)}$ Spirometry was performed with a portable spirometer (Easy One ${ }^{\circledR}$; ndd Medical Technologies, Inc., Andover, MA, USA). At all participating centers, the American Thoracic Society acceptability and reproducibility criteria were used. ${ }^{(16)}$

\section{Quantification of $A A T$}

The study was divided into three phases. In the first phase, all patients underwent determination of AAT levels in dried blood spot (DBS) samples in order to identify those with a possible diagnosis of AATD. In the second phase, patients with DBS AAT levels $\leq 2.64$ $\mathrm{mg} / \mathrm{dL}$ (suspected AATD) underwent determination of serum AAT levels. ${ }^{(17)}$ Finally, in the third phase, patients with serum AAT levels of $<113 \mathrm{mg} / \mathrm{dL}$ underwent genotyping. In case of conflicting results between serum AAT measurements and genotyping, genetic sequencing was performed (Figure 2). To determine the sensitivity and specificity of the eluate method, Zillmer et al. used the bootstrap resampling method, comparing the AAT values measured in serum with those measured in eluates from DBS samples in order to determine a cut-off point for AAT values in eluates; the value obtained was $2.02 \mathrm{mg} / \mathrm{dL}(97 \%$ CI: 1.45-2.64). ${ }^{(17)}$ All patients whose DBS AAT levels were below $2.64 \mathrm{mg} / \mathrm{dL}$ underwent measurement of serum AAT levels in order to prevent AATD from going undiagnosed.

\section{Genotyping}

Blood samples were collected with the use of filter paper cards (Whatman 903, lot W101; Whatman/ GE Healthcare, Florham Park, NJ, USA). They were transported to the Federal University of São Paulo Hospital São Paulo Central Laboratory, located in the city of São Paulo, Brazil, under temperature-controlled conditions (i.e., at a constant temperature of $-20^{\circ} \mathrm{C}$ ), in accordance with applicable International Air Transport Association regulations. All cards were stored at $-20^{\circ} \mathrm{C}$ for subsequent analysis (determination of DBS AAT levels, genotyping, and SERPINA1 gene sequencing). Serum and eluate samples were analyzed on a Siemens BNII system (Siemens Healthcare, Indianapolis, IN, USA) in July of 2012.

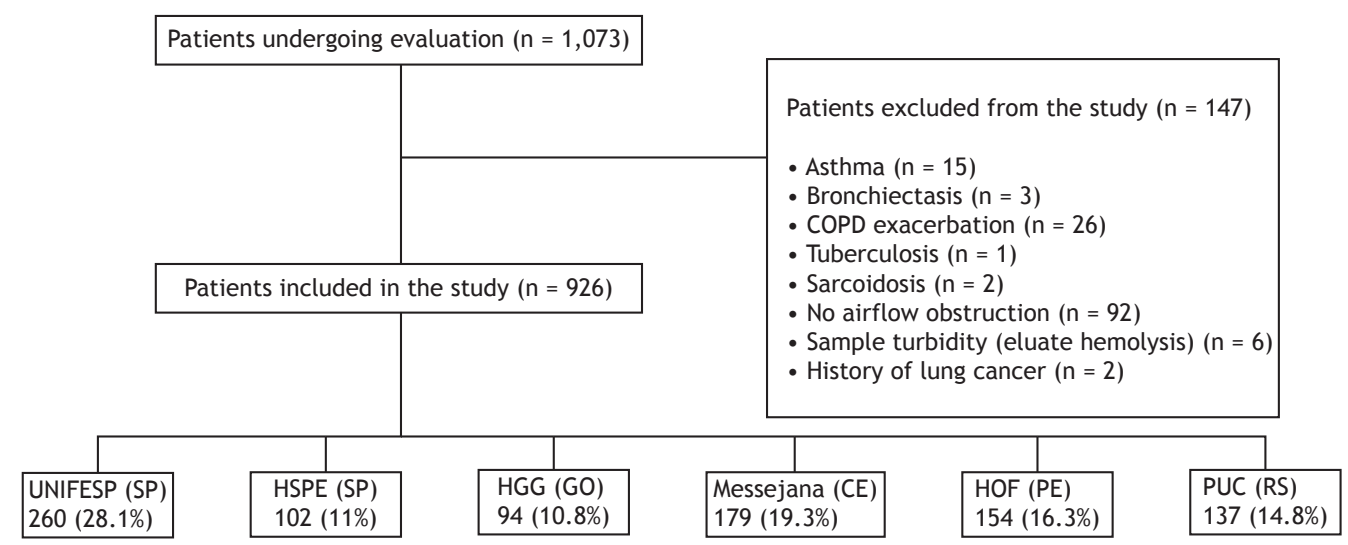

Figure 1. Flowchart of the patients included in the study and their distribution, by participating center. UNIFESP: Universidade Federal de São Paulo; HSPE-SP: Hospital do Servidor Público Estadual de São Paulo; HGG: Hospital Geral de Goiânia Alberto Rassi; Messejana: Hospital de Messejana; HOF: Hospital Otávio de Freitas; PUC: Pontifícia Universidade Católica; SP: Brazilian state of São Paulo; GO: Brazilian state of Goiás; CE: Brazilian state of Ceará; PE: Brazilian state of Pernambuco; and RS: Brazilian state of Rio Grande do Sul. 


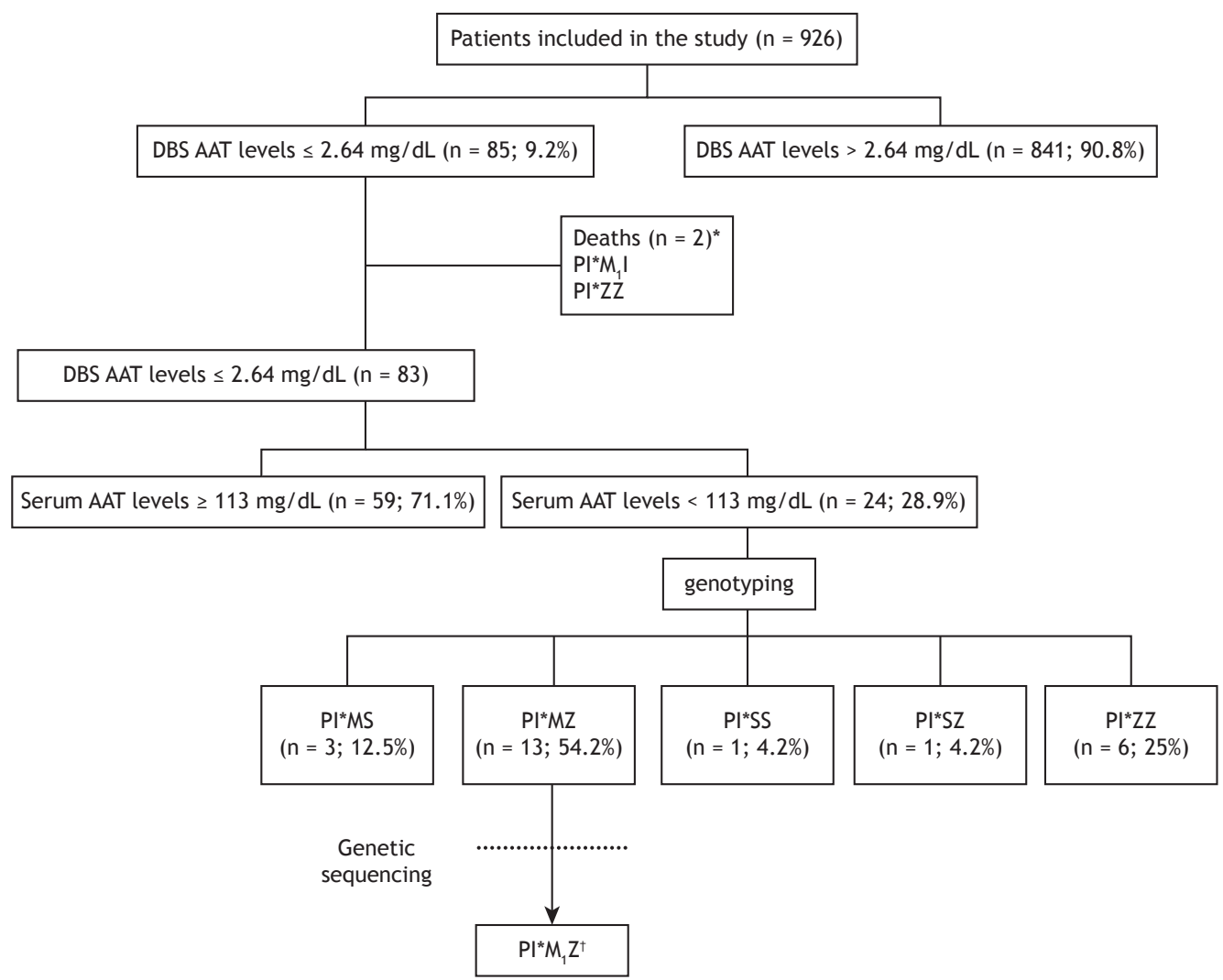

Figure 2. Flowchart of alpha 1-antitrypsin (AAT) deficiency screening and genotype distribution. PI: protease inhibitor; and DBS: dried blood spot. *Although 2 patients died before undergoing determination of serum AAT levels, SERPINA1 gene sequencing was performed with previously collected DBS samples. ${ }^{\dagger}$ Only $1 \mathrm{PI} * \mathrm{MZ}$ patient underwent gene sequencing, because of discrepant results between determination of serum AAT levels and genotyping.

For DNA extraction, DBS samples were removed from the cards with a 6-mm paper punch, DNA being extracted with the QIAamp DNA Blood Mini Kit (QIAGEN, Hilden, Germany), in accordance with the manufacturer instructions. For identification of $S$ and $Z$ alleles in exons 3 and 5, respectively, real-time PCR was used with TaqMan ${ }^{\circledR}$ SNP Genotyping Assays (Thermo Fisher Scientific Inc., Waltham, MA, USA). All patients with AATD but without $S$ and $Z$ alleles underwent SERPINA1 gene sequencing (exons 2-5) in order to identify other polymorphisms described in the literature.

\section{Statistical analysis}

Continuous variables were expressed as mean \pm standard deviation, whereas categorical variables were expressed as absolute numbers and proportions. Data were entered into an Oracle database and analyzed with the Statistical Package for the Social Sciences, version 18.0 for Windows (SPSS Inc., Chicago, IL, USA).

\section{RESULTS}

Of the 1,073 patients who were being followed at any of the six participating centers during the study period, 926 met the eligibility criteria and were therefore included in the study (Figure 1). The demographic characteristics of the patients included in the present study are shown in Table 1. There was no statistically significant difference between males and females regarding the prevalence of AATD, and two thirds of the participants were White. Although former smokers predominated (having accounted for $83.9 \%$ of the study sample), $36(3.7 \%)$ of the patients had never smoked; 410 patients ( $44.3 \%$ of the sample) had a body mass index within normal limits, and 56 $(6 \%)$ were underweight. As expected for patients with COPD, $\mathrm{FEV}_{1} / \mathrm{FVC} \%$ and percent predicted $\mathrm{FEV}_{1}$ were low, characterizing obstructive lung disease.

Of the 926 COPD patients included in the present study, 85 had DBS AAT levels $\leq 2.64 \mathrm{mg} / \mathrm{dL}$, therefore being suspected of having AATD. Of those 85 patients, 2 died. Therefore, 83 patients underwent determination of serum AAT levels. Of those 83 patients, 24 had serum AAT levels < $113 \mathrm{mg} / \mathrm{dL}$ and therefore underwent genotyping. Genotype distribution was as follows: PI*MS, in 3 (12.5\%); PI*MZ, in 13 (54.2\%); PI*SZ, in $1(4.2 \%)$; PI*SS, in $1(4.2 \%)$; and PI*ZZ, in 6 (25\%). Although determination of serum AAT levels was not performed in the 2 patients who had DBS AAT levels $\leq 2.64 \mathrm{mg} / \mathrm{dL}$ and died, genotyping and SERPINA1 gene sequencing were performed from the previously collected DBS samples, which had been stored at $-20^{\circ} \mathrm{C}$ for subsequent analysis. Genotype distribution was as follows: $\mathrm{PI}^{*} \mathrm{M}_{1} \mathrm{I}$, in 1 ; and $\mathrm{PI} * \mathrm{ZZ}$, 
in 1 (Figure 2). Given the discrepant results and the deaths, genetic sequencing was performed, and the following genotypes were found: $\mathrm{PI}^{*} \mathrm{M}_{1} \mathrm{Z} ; \mathrm{PI} * \mathrm{M}_{1} \mathrm{I}$; and PI*ZZ. These genotypes were included in a second analysis of allele frequency, and the results were as follows: PI*M, 28.8\%; PI*M, $3.8 \%$; $\mathrm{PI} * \mathrm{~S}, 11.5 \%$; PI*Z, 53.8\%; and PI*I, 1.9\%.

Table 2 shows the demographic characteristics of a subset of 24 patients with DBS AAT levels $\leq 2.64 \mathrm{mg} /$ $\mathrm{dL}$ and serum AAT levels $<113 \mathrm{mg} / \mathrm{dL}$. As expected, the patients with the PI*ZZ genotype were younger and had lower serum AAT levels than those with other genotypes $(p<0.001)$. However, there were no differences in gender, smoking history, spirometric values, Medical Research Council scale scores, or COPD Assessment Test scores across patient genotypes.

Among the 926 COPD patients included in the present study, the overall prevalence of AATD was $2.8 \%$ and the

Table 1. Demographic characteristics of the 926 COPD patients included in the present study.

\begin{tabular}{|c|c|}
\hline Characteristic & COPD patients $(N=926)$ \\
\hline \multicolumn{2}{|l|}{ Gender, n (\%) } \\
\hline Male & $522(56.4)$ \\
\hline Female & $404(43.6)$ \\
\hline \multicolumn{2}{|l|}{ Age, mean \pm SD } \\
\hline Age, years & $67.3 \pm 10.5$ \\
\hline \multicolumn{2}{|l|}{ Race/ethnicity, n (\%) } \\
\hline White & $612(66.1)$ \\
\hline Non-White & $314(33.9)$ \\
\hline \multicolumn{2}{|l|}{ Smoking status, n (\%) } \\
\hline Smokers & $113(12.2)$ \\
\hline Former smokers & 777 (83.9) \\
\hline Never smokers & $36(3.9)$ \\
\hline \multicolumn{2}{|l|}{ Lung function, mean $\pm S D$} \\
\hline $\mathrm{FEV}_{1} / \mathrm{FVC}$ & $0.45 \pm 0.10$ \\
\hline $\begin{array}{l}\mathrm{FEV}_{1} / \mathrm{FVC} \\
\% \text { of predicted }\end{array}$ & $61.0 \pm 13.8$ \\
\hline FVC, L & $2.43 \pm 0.76$ \\
\hline FVC, $\%$ of predicted & $75.6 \pm 20.2$ \\
\hline $\mathrm{FEV}_{1}, \mathrm{~L}$ & $1.12 \pm 0.45$ \\
\hline $\mathrm{FEV}_{1}, \%$ of predicted & $42.9 \pm 17.0$ \\
\hline
\end{tabular}

prevalence of the $\mathrm{PI} * \mathrm{ZZ}$ genotype (severe AATD) was $0.8 \%$. Analysis of allele frequency in the subgroup of patients with serum AAT levels $<113 \mathrm{mg} / \mathrm{dL}$ (including the alleles found in the 2 patients who died, whose DBS AAT levels were $\leq 2.64 \mathrm{mg} / \mathrm{dL}$ ) revealed frequencies of $53.8 \%, 11.5 \%$, and $1.9 \%$ for the $\mathrm{Z}$, S, and I alleles, respectively (Table 3 ). Table 4 shows the genotype prevalence among the five regions of Brazil.

\section{DISCUSSION}

This is the first study to show the prevalence of AATD, as well as allele frequency, in a population of COPD patients in Brazil. The prevalence of AATD (i.e., $2.8 \%$ ) and the $Z$ allele (i.e., $0.8 \%$ ) was found to be similar to that found in other countries. ${ }^{(18,19)}$

The decision to use the maximum confidence interval of the cut-off point for AAT values in eluates ${ }^{(17)}$ was due to the need to identify all individuals who were suspected of having AATD and should therefore undergo genotyping, thus minimizing the chances of not identifying patients with AATD. Although AATD is one of the most common genetic diseases, the prevalence of AATD is low. However, failure to identify any patient with AATD would have had an impact on the final results of the present study. Nevertheless, the use of the maximum confidence interval width resulted in more patients being re-evaluated. ${ }^{(17)}$ The cut-off point of $113 \mathrm{mg} / \mathrm{dL}$ was used in an attempt to

Table 3. Allele frequency in a subset of 24 COPD patients with serum alpha 1-antitrypsin levels $<113 \mathrm{mg} / \mathrm{dL}$, including the alleles found in 2 patients with dried blood spot alpha 1 -antitrypsin levels $\leq 2.64 \mathrm{mg} / \mathrm{dL}$, both of whom died.

$\begin{array}{lcc}\text { Allele } & \mathbf{n} & \% \\ \text { M } & 15 & 28.8 \\ M_{1} & 2 & 3.8 \\ \text { S } & 6 & 11.5 \\ \text { Z } & 28 & 53.8 \\ \text { I } & 1 & 1.9 \\ \text { Total } & 52 & 100\end{array}$

Genotypes include those in 2 patients who died (PI*M $I$ and $\mathrm{PI}^{*} \mathrm{ZZ}$ ) before undergoing determination of serum alpha 1-antitrypsin levels. PI: protease inhibitor.

Table 2. Demographic characteristics of a subset of 24 COPD patients with serum alpha 1-antitrypsin levels $<113$ $\mathrm{mg} / \mathrm{dL}$, by genotype. ${ }^{\mathrm{a}}$

\begin{tabular}{|c|c|c|c|c|c|c|}
\hline \multirow[t]{2}{*}{ Characteristic } & \multicolumn{5}{|c|}{ Genotype } & \multirow{2}{*}{ p* } \\
\hline & $\mathrm{PI} * \mathrm{MS}$ & $\mathrm{PI} * \mathrm{MZ}$ & PI*SS & $\mathbf{P I} * \mathbf{S Z}$ & $P I * Z Z$ & \\
\hline Male gender, n (\%) & $2(16.7)$ & $7(58.3)$ & $1(8.3)$ & $1(8.3)$ & $1(8.3)$ & 0.07 \\
\hline Age, years & $69.3 \pm 9.4$ & $69.0 \pm 10.1$ & 59.0 & 74.0 & $47.0 \pm 2.3$ & $<0.001$ \\
\hline Smoking history, pack-years & 55.0 & $53.5 \pm 41.1$ & 40.0 & 12.6 & $19.1 \pm 16.7$ & 0.07 \\
\hline Post-BD FEV ${ }_{1}, \%$ of predicted & $33.8 \pm 8.3$ & $41.1 \pm 14.0$ & 54.7 & 45.8 & $37.5 \pm 19.9$ & 0.63 \\
\hline $\mathrm{FEV}_{1} / \mathrm{FVC}$ & $49.4 \pm 5.8$ & $57.4 \pm 9.0$ & 59.0 & 56.5 & $55.7 \pm 12.6$ & 0.92 \\
\hline Serum AAT, mg/dL & $100 \pm 13.5$ & $93.7 \pm 14.0$ & 93.8 & 66.0 & $27.1 \pm 4.8$ & $<0.001$ \\
\hline MRC scale score & $2.6 \pm 1.1$ & $2.7 \pm 1.0$ & 3.0 & 2.0 & $3.3 \pm 1.6$ & 0.27 \\
\hline CAT score, total & $20.3 \pm 6.4$ & $16.6 \pm 7.3$ & 30 & 18 & $17.8 \pm 6.3$ & 0.42 \\
\hline Patients, $\mathrm{n}$ & 3 & 13 & 1 & 1 & 6 & N/A \\
\hline
\end{tabular}

PI: protease inhibitor; AAT: alpha 1-antitrypsin; MRC: Medical Research Council; BD: bronchodilator; and CAT: COPD Assessment Test. Values expressed as mean $\pm S D$, except where otherwise indicated. *PI*ZZ Vs. the remaining genotypes. 
Table 4. Genotypes involved in alpha 1-antitrypsin deficiency, distributed by mutation of the SERPINA1 gene (genotype) and by participating center.

\begin{tabular}{|c|c|c|c|c|c|c|}
\hline \multirow[t]{2}{*}{ Brazilian region/state } & \multicolumn{6}{|c|}{ Genotype } \\
\hline & $\mathrm{PI} * \mathrm{MZ}$ & $\mathbf{P I} * \mathbf{Z Z}$ & PI*MS & PI*SS & $P I * S Z$ & $P I * M_{1} I$ \\
\hline The northeast/Ceará & 3 & 3 & 1 & - & - & - \\
\hline The northeast/Recife & - & - & 1 & 1 & & \\
\hline The central-west/Goiás & - & 5 & - & - & - & - \\
\hline The southeast/São Paulo & 3 & 3 & - & & & 1 \\
\hline The south/Rio Grande do Sul & 2 & 1 & 1 & - & 1 & - \\
\hline
\end{tabular}

PI: protease inhibitor.

identify not only patients with severe AATD but also those with moderate AATD. ${ }^{(20-22)}$

Despite methodological differences and the fact that not all participants underwent genotyping, our results regarding the $\mathrm{PI} * \mathrm{Z}$ allele are similar to those found in the literature. $(11,18,23)$ The frequency of the mutant PI*Z allele and other AATD-associated alleles in the present study can be explained by the large number of immigrants from Europe, primarily from countries where the prevalence of AATD is high, such as Portugal and Italy. ${ }^{(23-26)}$

Although DBS analysis is particularly useful as an initial screening test for AATD, it is not sufficient for a definitive diagnosis. Clinical history, physical examination findings, and family history should be taken into account when interpreting the results, which should be confirmed by measuring serum AAT levels in patients suspected of having AATD. If the results of DBS analysis are confirmed by serum ATT measurements, genotyping or phenotyping are necessary for a definitive diagnosis.

Health professionals providing care to patients with COPD should bear in mind that $2.8 \%$ of all COPD patients have some degree of AATD. Our study reinforces the knowledge that AATD is one of the most prevalent genetic diseases. Further studies are warranted, given that an AATD diagnosis can have a major impact on COPD prevention, especially in young smokers. In addition, our finding that the prevalence of the $\mathrm{PI} * \mathrm{ZZ}$ genotype in the study population is $0.8 \%$ shows that severe AATD is present in patients with COPD in Brazil and reinforces the 1999 World Health Organization recommendation that "all COPD patients should be screened once for AATD using a quantitative test. Those with abnormal results on screening should undergo PI typing".(27) Determination of AAT levels in COPD patients has also been recommended by the American Thoracic
Society/European Respiratory Society ${ }^{(11)}$ and, more recently, the Canadian Thoracic Society. ${ }^{(28)}$ However, these patients typically present at a younger age $(<45$ years) with lower lobe emphysema. Family screening is useful for appropriate counseling. Few countries are as racially diverse as is Brazil, which is populated by a large number of immigrants, including Asians, Africans, Arabs, and, in particular, Europeans. The Portuguese brought centuries of genetic admixture among Europeans, including Celts, Romans, Germans, and Lusitanians. The differences in genotype prevalence among the five regions of Brazil might be due to the different immigrant origins.

One limitation of the present study is that not all participants underwent genotyping. However, serum AAT levels were measured in all patients with the use of the maximum confidence interval width, thus preventing AATD from going undiagnosed.

The prevalence of AATD in COPD patients in Brazil was found to be similar to that found in most countries, despite the racial diversity of the Brazilian population. The actual prevalence of AATD in this population can be best determined by investigating neonates. Genetic studies aimed at determining the ancestry of this population are critical in order to establish a correlation between mutated alleles and the actual ancestry of the individuals.

\section{ACKNOWLEDGMENTS}

We would like to thank Siemens for the technical and scientific support, which was crucial to the development of the present study. We would also like to thank Grifols Brasil Ltda. for their support in creating the database. Finally, we would like to thank the Associação Fundo de Incentivo à Pesquisa (AFIP, Association for the Incentive Funding of Research) for their technical support in performing the laboratory measurements.

\section{REFERENCES}

1. Fagerhol MK, Laurell CB. The polymorphism of "prealbumins" and alpha-1-antitrypsin in human sera. Clin Chim Acta. 1967;16(2):199203. http://dx.doi.org/10.1016/0009-8981(67)90181-7

2. Lai EC, Kao FT, Law ML, Woo SL. Assignment of the alpha 1-antitrypsin gene and a sequence-related gene to human chromosome 14 by molecular hybridization. Am J Hum Genet. 1983;35(3):385-92

3. Stoller JK, Aboussouan LS. Alpha1-antitrypsin deficiency. Lancet. 2005;365(9478):2225-36. http://dx.doi.org/10.1016/S01406736(05)66781-5

4. de Serres FJ. Worldwide racial and ethnic distribution of alpha1antitrypsin deficiency: summary of an analysis of published genetic epidemiologic surveys. Chest. 2002;122(5):1818-29. http://dx.doi. org/10.1378/chest.122.5.1818

5. Stockley RA. The pathogenesis of chronic obstructive lung diseases: implications for therapy. QJM. 1995;88(2):141-6.

6. Janoff A. Elastases and emphysema. Current assessment of the protease-antiprotease hypothesis. Am Rev Respir Dis. 1985; 132(2):417-33.

7. Celli BR, MacNee W; ATS/ERS Task Force. Standards for the 
diagnosis and treatment of patients with COPD: a summary of the ATS/ERS position paper. Eur Respir J. 2004;23(6):932-46. http:// dx.doi.org/10.1183/09031936.04.00014304

8. Silverman EK, Chapman HA, Drazen JM, Weiss ST, Rosner B, Campbell EJ, et al. Genetic epidemiology of severe, earlyonset chronic obstructive pulmonary disease. Risk to relatives for airflow obstruction and chronic bronchitis. Am J Respir Crit Care Med. 1998;157(6 Pt 1):1770-8. http://dx.doi.org/10.1164/ ajrccm.157.6.9706014

9. Lokke A, Lange P, Scharling H, Fabricius P, Vestbo J. Developing COPD: a 25 year follow up study of the general population. Thorax. 2006;61(11):935-9. http://dx.doi.org/10.1136/thx.2006.062802

10. Bascom R. Differential susceptibility to tobacco smoke: possible mechanisms. Pharmacogenetics. 1991;1(2):102-6. http://dx.doi. org/10.1097/00008571-199111000-00008

11. American Thoracic Society; European Respiratory Society. American Thoracic Society/European Respiratory Society statement: standards for the diagnosis and management of individuals with alpha-1 antitrypsin deficiency. Am J Respir Crit Care Med. 2003;168(7):818900. http://dx.doi.org/10.1164/rccm.168.7.818

12. de Serres FJ, Blanco I, Fernández-Bustillo E. Genetic epidemiology of alpha-1 antitrypsin deficiency in North America and Australia/New Zealand: Australia, Canada, New Zealand and the United States of America. Clin Genet. 2003;64(5):382-97. http://dx.doi.org/10.1034/ j.1399-0004.2003.00143.x

13. Menezes AM, Perez-Padilla R, Jardim JR, Muiño A, Lopez MV Valdivia G, et al. Chronic obstructive pulmonary disease in five Latin American cities (the PLATINO study): a prevalence study. Lancet. 2005;366(9500):1875-81. http://dx.doi.org/10.1016/S01406736(05)67632-5

14. Cazzola M, MacNee W, Martinez FJ, Rabe KF, Franciosi LG, Barnes PJ, et al. Outcomes for COPD pharmacological trials: from lung function to biomarkers. Eur Respir J. 2008;31 (2):416-69. http://dx.doi. org/10.1183/09031936.00099306

15. Hankinson JL, Odencrantz JR, Fedan KB. Spirometric reference values from a sample of the general U.S. population. Am J Respir Crit Care Med. 1999:159(1):179-87. http://dx.doi.org/10.1164/ ajrccm.159.1.9712108

16. Standardization of Spirometry, 1994 Update. American Thoracic Society. Am J Respir Crit Care Med. 1995;152(3):1107-36. http:// dx.doi.org/10.1164/ajrccm.152.3.7663792

17. Zillmer LR, Russo R, Manzano BM, Ivanaga I, Nascimento OA, Souza $A A$, et al. Validation and development of an immunonephelometric assay for the determination of alpha-1 antitrypsin levels in dried blood spots from patients with COPD. J Bras Pneumol. 2013;39(5):547-54
http://dx.doi.org/10.1590/S1806-37132013000500004

18. Lieberman J, Winter B, Sastre A. Alpha 1-antitrypsin Pi-types in 965 COPD patients. Chest. 1986;89(3):370-3. http://dx.doi.org/10.1378/ chest.89.3.370

19. de la Roza C, Costa X, Vidal R, Vilá S, Rodríguez-Frias F, Jardí R, et al. Screening program for alpha-1 antitrypsin deficiency in patients with chronic obstructive pulmonary disease, using dried blood spots on filter paper [Article in Spanish]. Arch Bronconeumol. 2003;39(1):8-12.

20. Costa X, Jardi R, Rodriguez F, Miravitlles M, Cotrina M, Gonzalez C, et al. Simple method for alpha1-antitrypsin deficiency screening by use of dried blood spot specimens. Eur Respir J. 2000;15(6):1111-5.

21. Miravitlles M, Herr C, Ferrarotti I, Jardi R, Rodriguez-Frias F, Luisett $M$, et al. Laboratory testing of individuals with severe alpha1antitrypsin deficiency in three European centres. Eur Respir $\mathrm{J}$. 2010;35(5):960-8. http://dx.doi.org/10.1183/09031936.00069709

22. Ferrarotti I, Scabini R, Campo I, Ottaviani S, Zorzetto M, Gorrini M, et al. Laboratory diagnosis of alpha1-antitrypsin deficiency. Transl Res. 2007;150(5):267-74. Erratum in: Transl Res. 2008;151(4):232. http:// dx.doi.org/10.1016/j.trsl.2007.08.001

23. Vidal R, Blanco I, Casas F, Jardí R, Miravitlles M; Committee on the National Registry of Individuals with Alpha-1 Antitrypsin Deficiency. Guidelines for the diagnosis and management of alpha-1 antitrypsin deficiency [Article in Spanish]. Arch Bronconeumol. 2006;42(12):64559. http://dx.doi.org/10.1157/13095974

24. Blanco I, Fernández E, Bustillo EF. Alpha-1-antitrypsin PI phenotypes $S$ and $Z$ in Europe: an analysis of the published surveys. Clin Genet. 2001;60(1):31-41. http://dx.doi.org/10.1034/j.1399$0004.2001 .600105 . x$

25. Sitkauskiene B, Serapinas D, Blanco I, Fernández-Bustillo E Janciauskiene S, Sakalauskas R. Screening for alpha1-antitrypsin deficiency in Lithuanian patients with COPD. Respir Med. 2008:102(11):1654-8. http://dx.doi.org/10.1016/..rmed.2008.07.003

26. Blanco I, de Serres FJ, Cárcaba V, Lara B, Fernández-Bustillo E. Alpha-1 Antitrypsin Deficiency PI*Z and $\mathrm{PI}^{*} \mathrm{~S}$ Gene Frequency Distribution Using on Maps of the World by an Inverse Distance Weighting (IDW) Multivariate Interpolation Method. Hepat Mon. 2012;12(10 HCC):e7434.

27. Alpha 1-antitrypsin deficiency: memorandum from a WHO meeting Bull World Health Organ. 1997;75(5):397-415.

28. Marciniuk DD, Hernandez $P$, Balter M, Bourbeau J, Chapman KR, Ford GT, et al. Alpha-1 antitrypsin deficiency targeted testing and augmentation therapy: a Canadian Thoracic Society clinica practice guideline. Can Respir J. 2012;19(2):109-16. http://dx.doi. org/10.1155/2012/920918 